\title{
Effects of Gibberellic acid, micronutrient fertilizer and Calcium nitrate foliar fertilizer on growth and yield of tomato Solanum lycopersicum $\mathbf{L}$. cultivated in Vietnam
}

\author{
Van T. Le ${ }^{1}$, Bao T. Bui ${ }^{2 *}$ \\ ${ }^{1}$ Faculty of Natural Sciences, Hong Duc University, Thanh Hoa, Vietnam \\ ${ }^{2}$ Far Eastern Federal University, Vladivostok, Russian Federation \\ *Corresponding author: bbt.9895@gmail.com
}

\begin{abstract}
In this study, we present the experimental results which evaluate the influence of Gibberellic acid $\mathrm{GA}_{3}$, micronutrient fertilizer and Calcium nitrate $\mathrm{Ca}\left(\mathrm{NO}_{3}\right)_{2}$ foliar fertilizer on the growth and yield of tomato cultivar NHP11 cultivated in a net house located in Thanh Hoa province, Vietnam. The experiment including 8 formulas was laid out in a randomized complete block design (RCBD) with three replications. In treatments with the application of $\mathrm{GA}_{3}$, micronutrient fertilizer and $\mathrm{Ca}\left(\mathrm{NO}_{3}\right)_{2}$ foliar fertilizer, plants were observed to grow better than the control (via some indicators such as plant height, leaf area index, number of flowers per plant, effective flower rate, number of fruits per plant, average fruit weight per plant). The yields differed due to different formulas on tomato. Results indicated that the highest yield was recorded at 50.73 tons $\mathrm{ha}^{-1}$ when the combination of $\mathrm{GA}_{3}$, micronutrient fertilizer and $\mathrm{Ca}\left(\mathrm{NO}_{3}\right)_{2}$ foliar fertilizer was applied in F8, followed by the record of 47.31 tons ha ${ }^{-1}$ in F6 (in presence of $\mathrm{GA}_{3}$ and $\mathrm{Ca}\left(\mathrm{NO}_{3}\right)_{2}$ foliar fertilizer), 46.55 tons ha ${ }^{-1}$ in $\mathrm{F} 5$ (in presence of $\mathrm{GA}_{3}$ and micronutrient fertilizer), 45.79 tons ha ${ }^{-1}$ in $\mathrm{F} 7$ (in presence of $\mathrm{Ca}\left(\mathrm{NO}_{3}\right)_{2}$ foliar fertilizer and micronutrient fertilizer). The yields of tomato in F2, F3, F4 when treated with supplemented separately $\mathrm{GA}_{3}$, micronutrient fertilizer and $\mathrm{Ca}\left(\mathrm{NO}_{3}\right)_{2}$ foliar fertilizer respectively were higher than those of the control $\left(39.90\right.$ tons ha $\left.{ }^{-1}\right)$ but lower than the yield in mixed formulas. Results show that the treatment combination of $\mathrm{GA}_{3}$, micronutrient fertilizer and $\mathrm{Ca}\left(\mathrm{NO}_{3}\right)_{2}$ foliar fertilizer can promote the growth and yield of tomato.
\end{abstract}

Key words: tomato, Solanum lycopersicum, $\mathrm{GA}_{3}$, micronutrient fertilizer, $\mathrm{Ca}\left(\mathrm{NO}_{3}\right)_{2}$ foliar fertilizer, growth, yield

\section{Acknowledgments:}

Hong Duc University, Vietnam is appreciated for supporting this research.

\section{Author contributions:}

LVT conceived and planned the research, set-up the experiments, collected and analyzed the data, and wrote the initial draft of the manuscript. BBT planned and set up the experiments, analyzed the data, wrote and edited the manuscript.

\section{Le V.T., Bui B.T., 2019.}

This work is licensed under a Creative Commons Attribution 4.0 International License https://creativecommons.org/licenses/by/4.0/ 


\section{Conflicts of interest:}

The authors declare no conflicts of interest.

Article history:

Received: 18 August 2019. Accepted: 11 October 2019

\section{For citation:}

Le VT, Bui BT. Effects of Gibberellic acid, micronutrient fertilizer and Calcium nitrate foliar fertilizer on growth and yield of tomato Solanum lycopersicum L. cultivated in Vietnam. RUDN Journal of Agronomy and Animal Industries, 2019; 14(4):306-318. doi: 10.22363/2312-797X-2019-14-4306-318

\section{Introduction}

Tomato (Solanum lycopersicum L.), among current cultivated vegetables in the world, is one of the most important crops with the highest yield and largest cultivation area [1]. Tomato fruits contain a huge amount of nutrients including glucid, many organic acids and major antioxidants such as Lycopene, Phenolic, and Vitamin C [2-4]. It also has a high medicinal value thanks to its sweet taste and cooling nature. Phytochemicals in tomatoes can act as antimicrobials and antitoxin agents, reduce the risk of cardiovascular diseases, contributing to the prevention of the formation of free radicals which might lead to cancers, especially prostate cancer [5-7]. In addition, tomato is easily cultivated under various climatic conditions, offering great financial support for many farmer households. As a result, tomato has been widely cultivated in many countries including Vietnam.

Results of studies in the world have shown that Gibberellic acid $\mathrm{GA}_{3}$, micronutrient fertilizer and Calcium nitrate $\mathrm{Ca}\left(\mathrm{NO}_{3}\right)_{2}$ foliar fertilizer play essential roles in vegetative growth. $\mathrm{GA}_{3}$ is a plant hormone that can regulate the growth of plants, stem elongation, germination, dormancy, flowering, genetic development, and enzyme activation [8]. Micronutrient fertilizer includes a variety of metallic and non-metallic elements. For crops, micronutrient fertilizer is essential because of their role in beneficial enzymes for plant growth. The deficiency of any micro-element in soil might significantly reduce the vegetative yield and quality [9]. $\mathrm{Ca}\left(\mathrm{NO}_{3}\right)_{2}$ foliar fertilizer facilitates the process of nutrients and soluble calcium absorption makes the stem bigger and stronger, increases plant resistance to diseases and pests, improves the root length and root branching evolution, thus helping plants absorb more nutrients [10].

Population explosion is a threat to global agriculture. There have been increasing demands for edible products in terms of quantity and quality [11]. When it comes to agricultural research, increasing crop yield is an essential priority [12]. Effects of $\mathrm{GA}_{3}$, micronutrient fertilizer and $\mathrm{Ca}\left(\mathrm{NO}_{3}\right)_{2}$ foliar fertilizer on vegetative growth and yield have become common research topics [10, 13, 14]. However, the comprehensive reports on the influences of $\mathrm{GA}_{3}$, micronutrients fertilizer and $\mathrm{Ca}\left(\mathrm{NO}_{3}\right)_{2}$ foliar fertilizer on the growth and yield of tomato cultivated in Vietnam is quite limited. The purpose of this study was to assess the effects of $\mathrm{GA}_{3}$, micronutrient fertilizer and $\mathrm{Ca}\left(\mathrm{NO}_{3}\right)_{2}$ foliar fertilizer on the growth and yield of tomato cultivated in net houses in Vietnam. 


\section{Materials and methods}

Research materials. Tomato cultivar NHP11, which is widely cultivated in Vietnam, was provided by Nong Hung Phu Co., Ltd. Organic substrate QD02 consists of alluvium, peat, mushroom residues, burnt rice husk and lime powder. Micronutrient fertilizer B6 includes 2\% $\mathrm{K}_{2} \mathrm{O}, 800$ ppm Cu, 50 ppm Mo, 900 ppm Zn, 1000 ppm Bo, 1200 ppm $\mathrm{Mg}$. $\mathrm{Ca}\left(\mathrm{NO}_{3}\right)_{2}$ foliar fertilizer comprises $\mathrm{Ca}\left(\mathrm{NO}_{3}\right)_{2}, 26.5 \% \mathrm{CaO}, 15.5 \% \mathrm{~N}$. Gibberellic acid $\left(\mathrm{GA}_{3}\right)$ and NPK fertilizer with the ratio of $4 \mathrm{~kg} \mathrm{~N}: 4 \mathrm{~kg} \mathrm{P}_{2} \mathrm{O}_{5}: 3 \mathrm{~kg} \mathrm{~K} \mathrm{~K}_{2} \mathrm{O}$ were also used.

Experimental arrangement. The experiment was conducted from November 2018 to March 2019 in a net house located in Quang Xuong district, Thanh Hoa province, Vietnam. The experiment including 8 formulas (table 1) was laid out in a randomized complete block design (RCBD) with three replications.

Table 1

\section{Components of formulas}

\begin{tabular}{|c|l|}
\hline Formula & \multicolumn{1}{c|}{ Components } \\
\hline F1 & Soil + NPK fertilizer + Organic substrate (control) \\
\hline F2 & Soil + NPK fertilizer + Organic substrate $+\mathrm{GA}_{3}$ \\
\hline F3 & Soil + NPK fertilizer + Organic substrate + Micronutrient fertilizer \\
\hline F4 & Soil + NPK fertilizer + Organic substrate $+\mathrm{Ca}\left(\mathrm{NO}_{3}\right)_{2}$ foliar fertilizer \\
\hline F5 & Soil + NPK fertilizer + Organic substrate $+\mathrm{GA}_{3}+\mathrm{Micronutrient}$ fertilizer \\
\hline F6 & Soil + NPK fertilizer + Organic substrate $+\mathrm{GA}_{3}+\mathrm{Ca}\left(\mathrm{NO}_{3}\right)_{2}$ foliar fertilizer \\
\hline F7 & Soil + NPK fertilizer + Organic substrate $+\mathrm{Micronutrient}$ fertilizer $+\mathrm{Ca}\left(\mathrm{NO}_{3}\right)_{2}$ foliar fertilizer \\
\hline F8 & Soil + NPK fertilizer + Organic substrate $+\mathrm{GA}_{3}+$ Micronutrient fertilizer $+\mathrm{Ca}\left(\mathrm{NO}_{3}\right)_{2}$ foliar fertilizer \\
\hline
\end{tabular}

Experimental technical process. Pots sized $35 \times 40 \mathrm{~cm}$ with bottom holes were used. $10 \mathrm{~kg}$ of soil were initially put inside, then $4 \mathrm{~kg}$ of organic substrate were added into each pot. Each seedling at the height of $20 \mathrm{~cm}$ was transplanted into one pot. Seedlings were planted deep with $50 \%$ of their stem underground because the root development would soon improve, making the tomato plants much stronger and more resistant. The amount of $0.5 \mathrm{~kg}$ of NPK was applied in different growth stages: fertilization before planting seedlings; first supplementary fertilization after the seedlings had new roots for $4-5$ days; second supplementary fertilization at the profusely flowering stage; third supplementary fertilization when fruits had been fully mature (15 days after the second supplementary fertilization); fourth supplementary fertilization after first harvesting.

In experimental treatments, for the treatment combination of $\mathrm{GA}_{3}$, micronutrient fertilizer and $\mathrm{Ca}\left(\mathrm{NO}_{3}\right)_{2}$ foliar fertilizer, doses and rates were ensured. $\mathrm{GA}_{3}$ at a dose of $30 \mathrm{ppm}$ and the rate of $30 \mathrm{~mL} / \mathrm{m}^{2}$ was sprayed into leaves and stems at beginning of the flowering stage and after the first harvesting. Micronutrient fertilizer at a concentration of $0.03 \%$ was applied around the stems which were covered by leaves after the seedlings had new roots, before the flowering stage and after the first harvesting. $\mathrm{Ca}\left(\mathrm{NO}_{3}\right)_{2}$ foliar fertilizer at a concentration of $0.03 \%$ was sprayed into leaves after the seedlings had new roots, before the flowering stage and after the first harvesting.

Data collection. Data on growth, development and yield variables of tomato plants such as: plant height (from the ground to shoot tip, measured with a measuring tape 
with a precision of $1 \mathrm{~mm}$ ), number of flower clusters per stem; number of flowers per cluster, effective flower rate (calculated by dividing the number of flowers that produce the fruit by the total number of initial flowers), leaf area measured by CI-202 Leaf Area Meter originated from the USA; Leaf area index (LAI); number of fruits per plant; average fruit weight per plant; actual yield (measured by using the total fruit weight per plant until the end of harvesting).

Those data were collected at 4 different stages: beginning of rooting stage (when above $50 \%$ of the seedlings in the treatment had new roots): 8 days after transplanting; beginning of flowering stage (when the initiation of flowers had been recorded in more than $50 \%$ of the plants in the treatment): 20 days after transplanting; beginning of harvesting stage (when $50 \%$ of the plants in the treatment had reached the harvesting): 70 days after transplanting; after harvesting: 125 days after transplanting.

Statistical analysis. All experiments were conducted three times independently. The results are expressed as mean values and standard deviation (SD). The results were subjected to an analysis of variance (ANOVA). Data were compared according to Tukey's test using IRRISTAT software (version 5.0) for Windows computers.

\section{Results and discussion}

Plant height. Plant height, which is one of the major parameters in plant growth, is strongly connected to the resistance and plant yield [15]. Plant height was recorded at 4 different stages. Among formulas, the difference in the fertilizer combinations led to the difference in plant height variables. Obtained data on plant height are illustrated in Table 2 .

Table 2

Effects ofGA ${ }_{3}$, micronutrient fertilizer and $\mathrm{Ca}\left(\mathrm{NO}_{3}\right)_{2}$ foliar fertilizer on tomato plant height

\begin{tabular}{|c|c|c|c|c|}
\hline \multirow{2}{*}{ Formula } & \multicolumn{4}{|c|}{ Plant height $(\mathrm{cm})$} \\
\cline { 2 - 5 } & $\begin{array}{c}\text { Beginning } \\
\text { of rooting stage }\end{array}$ & $\begin{array}{c}\text { Beginning } \\
\text { of flowering stage }\end{array}$ & $\begin{array}{c}\text { Beginning } \\
\text { of harvesting stage }\end{array}$ & After harvesting \\
\hline F1 & $17.50 \mathrm{~b} \pm 0.095$ & $41.54 \mathrm{~d} \pm 0.076$ & $75.15 \mathrm{~d} \pm 0.165$ & $77.32 \mathrm{c} \pm 0.352$ \\
\hline F2 & $17.62 \mathrm{~b} \pm 0.027$ & $49.75 \mathrm{~b} \pm 0.135$ & $84.67 \mathrm{~b} \pm 0.157$ & $86.28 \mathrm{~b} \pm 0.265$ \\
\hline F3 & $16.58 \mathrm{c} \pm 0.136$ & $41.67 \mathrm{~d} \pm 0.149$ & $77.61 \mathrm{~cd} \pm 0.248$ & $78.42 \mathrm{c} \pm 0.146$ \\
\hline F4 & $18.23 \mathrm{a} \pm 0.062$ & $42.58 \mathrm{~d} \pm 0.082$ & $76.59 \mathrm{~cd} \pm 0.087$ & $78.53 \mathrm{c} \pm 0.312$ \\
\hline F5 & $16.42 \mathrm{c} \pm 0.084$ & $51.03 \mathrm{a} \pm 0.046$ & $88.41 \mathrm{a} \pm 0.160$ & $89.76 \mathrm{a} \pm 0.295$ \\
\hline F6 & $17.08 \mathrm{bc} \pm 0.125$ & $50.16 \mathrm{~b} \pm 0.154$ & $86.54 a b \pm 0.053$ & $89.51 \mathrm{a} \pm 0.119$ \\
\hline F7 & $18.15 \mathrm{a} \pm 0.018$ & $44.02 \mathrm{c} \pm 0.096$ & $78.62 \mathrm{c} \pm 0.169$ & $79.05 \mathrm{c} \pm 0.207$ \\
\hline F8 & $16.31 \mathrm{c} \pm 0.054$ & $51.28 \mathrm{a} \pm 0.068$ & $90.04 \mathrm{a} \pm 0.237$ & $92.18 \mathrm{a} \pm 0.128$ \\
\hline
\end{tabular}

Note: Numbers represent mean values of three independent replicates \pm SD. In the same data column, values with similar letters represent non-significant differences, values with different letters represent differences in significance $(P \leq 0.05)$.

At beginning of the rooting stage, when supplementary $\mathrm{GA}_{3}$ and fertilizers had not been applied, no significant difference in plant height parameters could be found (Table 2). The highest plant height was observed in F4 $(18.23 \mathrm{~cm})$ and the lowest was found in F8 $(16.31 \mathrm{~cm})$. The average plant height among 8 treatments was $17.24 \mathrm{~cm}$. From the beginning of flowering to the end of harvesting, plant height variables found 
in 8 treatments were significantly different. At beginning of the flowering stage, the average plant height among 8 treatments was $46.50 \mathrm{~cm}$, in which the maximum was observed in F8 $(51.28 \mathrm{~cm})$, followed by F5 $(51.03 \mathrm{~cm}), \mathrm{F} 6(50.16 \mathrm{~cm})$, and F2 $(49.75 \mathrm{~cm})$. In these formulas, supplementary $\mathrm{GA}_{3}$ was applied, and it was one of the major factors that contributed to the development of plant height [16]. Additionally, micronutrient fertilizer and $\mathrm{Ca}\left(\mathrm{NO}_{3}\right)_{2}$ foliar fertilizer were also applied in $\mathrm{F}$, leading to the highest plant height value found in this formula. The minimum plant height was found in F1 (the control) at only $41.54 \mathrm{~cm}$. At beginning of the harvesting stage, plants grew quickly, reaching the average plant height of $80.20 \mathrm{~cm}$; the highest plant height was again found in F8 $(90.04 \mathrm{~cm})$, followed by F5 $(88.41 \mathrm{~cm})$ and the lowest was again found in F1 $(75.15 \mathrm{~cm})$. After the harvesting stage, the plant height values continued to increase, but slightly. The maximum plant height was observed in F8 $(92.18 \mathrm{~cm})$ and the minimum was observed in F1 $(77.32 \mathrm{~cm})$.

Experimental results among 8 treatments show that $\mathrm{GA}_{3}$ application has a significant impact on tomato plant height [16]. Besides, supplementary $\mathrm{Ca}\left(\mathrm{NO}_{3}\right)_{2}$ and micronutrient fertilization can improve the height of tomato plants. In treatments applying isolated micronutrient fertilizer or $\mathrm{Ca}\left(\mathrm{NO}_{3}\right)_{2}$ foliar fertilizer or their mixture in absence of $\mathrm{GA}_{3}$, tomato plants could grow higher than the control group [17], but lower than the plants supplementarily treated with $\mathrm{GA}_{3}$ in other treatment combinations. It is concluded that $\mathrm{GA}_{3}$, micronutrient fertilizer and $\mathrm{Ca}\left(\mathrm{NO}_{3}\right)_{2}$ foliar fertilizer have great effects on the plant height of tomato; however, the rates of effect might vary.

Number of flowers and effective flower rate. The production of flowers is the main element contributing to the success of fruit setting [18]. The number of flowers is considered to be the first yield characters of plants [19]. After pollination and fertilization, flowers set and develop into fruits. Fertilizer application promotes the profuse flowering, the number of flowers as well as the effective flower rate [20, 21]. In this experiment, the effects of $\mathrm{GA}_{3}$, micronutrient fertilizer and $\mathrm{Ca}\left(\mathrm{NO}_{3}\right)_{2}$ foliar fertilizer on the number of flowers and effective flower rate of tomato were analyzed.

Table 3

Effects of $\mathrm{GA}_{3}$, micronutrient fertilizer and $\mathrm{Ca}\left(\mathrm{NO}_{3}\right)_{2}$ foliar fertilizer on the number of flowers and effective flower rate of tomato

\begin{tabular}{|c|c|c|c|c|}
\hline Formula & $\begin{array}{c}\text { Number of flowers } \\
\text { per cluster }\end{array}$ & $\begin{array}{c}\text { Number of flowers } \\
\text { clusters per stem }\end{array}$ & $\begin{array}{c}\text { Total number } \\
\text { of flowers per plant }\end{array}$ & $\begin{array}{c}\text { Effective flower rate } \\
(\%)\end{array}$ \\
\hline F1 & $6.12 \mathrm{c} \pm 0.034$ & $5.25 \mathrm{~d} \pm 0.063$ & $40.78 \mathrm{~d} \pm 0.067$ & $57.06 \mathrm{c} \pm 0.109$ \\
\hline F2 & $7.05 \mathrm{~b} \pm 0.046$ & $6.64 \mathrm{~b} \pm 0.025$ & $43.88 \mathrm{~b} \pm 0.084$ & $61.38 \mathrm{~b} \pm 0.086$ \\
\hline F3 & $6.89 \mathrm{~b} \pm 0.053$ & $5.49 \mathrm{~d} \pm 0.009$ & $42.10 \mathrm{c} \pm 0.049$ & $58.74 \mathrm{bc} \pm 0.157$ \\
\hline F4 & $6.93 \mathrm{~b} \pm 0.015$ & $6.37 \mathrm{bc} \pm 0.014$ & $42.15 \mathrm{c} \pm 0.134$ & $60.26 \mathrm{~b} \pm 0.050$ \\
\hline F5 & $6.42 \mathrm{c} \pm 0.023$ & $6.71 \mathrm{~b} \pm 0.057$ & $44.06 \mathrm{a} \pm 0.019$ & $65.37 \mathrm{a} \pm 0.036$ \\
\hline F6 & $6.92 \mathrm{~b} \pm 0.071$ & $6.23 \mathrm{bc} \pm 0.020$ & $43.09 \mathrm{~b} \pm 0.107$ & $64.82 \mathrm{a} \pm 0.129$ \\
\hline F7 & $7.07 \mathrm{~b} \pm 0.042$ & $6.05 \mathrm{c} \pm 0.016$ & $42.76 \mathrm{~b} \pm 0.074$ & $65.16 \mathrm{a} \pm 0.095$ \\
\hline F8 & $8.01 \mathrm{a} \pm 0.058$ & $7.35 \mathrm{a} \pm 0.012$ & $44.19 \mathrm{a} \pm 0.038$ & $66.81 \mathrm{a} \pm 0.048$ \\
\hline
\end{tabular}

Note: Numbers represent mean values of three independent replicates \pm SD. In the same data column, values with similar letters represent non-significant differences, values with different letters represent differences in significance $(P \leq 0.05)$. 
As shown in Table 3, the maximum number of flower clusters per stem (7.35), the maximum number of flowers per cluster (8.01), thus the maximum total number of flowers per plant (44.19) and the maximum effective flower rate (66.81\%) were all found in $\mathrm{F} 8$ (in presence of $\mathrm{GA}_{3}$, micronutrient fertilizer and $\mathrm{Ca}\left(\mathrm{NO}_{3}\right)_{2}$ foliar fertilizer). It could be observed from F5 (in presence of $\mathrm{GA}_{3}$ and micronutrient fertilizer) that the total number of flowers per plant was 44.06 while the number of flowers per cluster was 6.42 and the number of flower clusters was 6.37 per stem. The differences between results gained from $\mathrm{F} 5$ and $\mathrm{F} 8$ and those gained from other treatments had statistical significance. In $\mathrm{F} 6$ (in presence of $\mathrm{GA}_{3}$ and $\mathrm{Ca}\left(\mathrm{NO}_{3}\right)_{2}$ foliar fertilizer), the number of flowers per cluster was 6.92, the number of flower clusters per stem was 6.23 and the total number of flowers was 43.09 per plant; in F7 (in presence of micronutrient fertilizer and $\mathrm{Ca}\left(\mathrm{NO}_{3}\right)_{2}$ foliar fertilizer), the number of flowers per cluster reached 7.07 while the number of flower clusters was only 6.05 per stem, leading to the moderate number of flowers which was only 42.76 per plant. Besides, higher number of flowers per cluster was found in F2 with the total flower number of 43.88 per plant; however, the effective flower rate was recorded at $61.38 \%$ only, lower than that gained in F5, F6, F7 and F8. The minimum numbers of flowers per plant and flower clusters per stem were observed in F1 (the control), thus the total number of flowers per plant and effective flower rate were 40.78 and $57.06 \%$ respectively. In other formulas (F3 and F4), the total number of flowers and effective flower rate, although higher than those of the control, just reached the average values. Results show that the application of $\mathrm{GA}_{3}$ spray on tomato could increase the number of flowers and effective flower rate, especially in treatment combination in the presence of micronutrient fertilizer and $\mathrm{Ca}\left(\mathrm{NO}_{3}\right)_{2}$ foliar fertilizer. In formulas with isolated $\mathrm{Ca}\left(\mathrm{NO}_{3}\right)_{2}$ foliar fertilizer or micronutrient fertilizer, there was also a growth in the number of flowers and effective flower rate, but they were recorded at average values only. It can be referred that $\mathrm{GA}_{3}$, micronutrient fertilizer and $\mathrm{Ca}\left(\mathrm{NO}_{3}\right)_{2}$ foliar fertilizer all have impacts on the number of flowers and effective flower rate, thus affecting the yield of tomato.

Leaf area index (LAI). There is a close connection between the leaf area index (LAI) and plant photosynthesis. Cultivars with higher leaf area index often gain higher yield production, although the structures of plant populations have a great influence on this index value [22]. If the leaf area index is recorded high, but the population is unreasonably structured, the leaves will shade each other, leading to a decrease in photosynthesis while the demand for respiration increases. As a result, photosynthetic biomass will drop [23]. Experimental results on LAI are presented in Table 4.

Among mentioned formulas, the LAI values for tomato were recorded to increase from the beginning of rooting to the end of harvesting (Table 4). At the beginning of rooting, in absence of supplementary $\mathrm{Ca}\left(\mathrm{NO}_{3}\right)_{2}$ foliar fertilizer, micronutrient fertilizer and $\mathrm{GA}_{3}$, LAI values slightly varied among the formulas. The maximum LAI was obtained in F2 at $0.31\left(\mathrm{~m}^{2} / \mathrm{m}^{2}\right)$ while the minimum was found in F5 at $0.26\left(\mathrm{~m}^{2} / \mathrm{m}^{2}\right)$. From the beginning of flowering to the harvesting, under the influence of plant growth regulator $\mathrm{GA}_{3}$ and fertilizers, LAI values among the formulas changed sharply with statistical significance. The highest LAI values were recorded in F8 during the experimental period from the beginning of flowering to the end of harvesting. At the beginning of flowering, LAI found in F8 was $1.41\left(\mathrm{~m}^{2} / \mathrm{m}^{2}\right)$, followed by that in F5 $\left(1.35 \mathrm{~m}^{2} / \mathrm{m}^{2}\right)$, 
Effects of $\mathrm{GA}_{3}$, micronutrient fertilizer and $\mathrm{Ca}\left(\mathrm{NO}_{3}\right)_{2}$ foliar fertilizer on tomato leaf area index (LAI)

\begin{tabular}{|c|c|c|c|c|}
\hline \multirow{2}{*}{ Formula } & \multicolumn{3}{|c|}{ Leaf area index (leaf area / ground area, $\mathrm{m}^{2} / \mathrm{m}^{2}$ ) } \\
\cline { 2 - 5 } & $\begin{array}{c}\text { Beginning } \\
\text { of rooting stage }\end{array}$ & $\begin{array}{c}\text { Beginning of flowering } \\
\text { stage }\end{array}$ & $\begin{array}{c}\text { Beginning of harvesting } \\
\text { stage }\end{array}$ & After harvesting \\
\hline F1 & $0.28 \mathrm{bc} \pm 0.002$ & $1.08 \mathrm{c} \pm 0.007$ & $2.87 \mathrm{c} \pm 0.017$ & $3.29 \mathrm{c} \pm 0.018$ \\
\hline F2 & $0.31 \mathrm{a} \pm 0.005$ & $1.24 \mathrm{~b} \pm 0.005$ & $3.05 \mathrm{~b} \pm 0.009$ & $3.65 \mathrm{a} \pm 0.007$ \\
\hline F3 & $0.27 \mathrm{~cd} \pm 0.001$ & $1.13 \mathrm{c} \pm 0.003$ & $3.17 \mathrm{a} \pm 0.015$ & $3.58 \mathrm{ab} \pm 0.005$ \\
\hline F4 & $0.29 \mathrm{ab} \pm 0.003$ & $1.28 \mathrm{~b} \pm 0.001$ & $2.89 \mathrm{c} \pm 0.007$ & $3.34 \mathrm{bc} \pm 0.013$ \\
\hline F5 & $0.26 \mathrm{~d} \pm 0.002$ & $1.35 \mathrm{a} \pm 0.001$ & $3.08 \mathrm{ab} \pm 0.012$ & $3.72 \mathrm{a} \pm 0.008$ \\
\hline F6 & $0.29 \mathrm{ab} \pm 0.001$ & $1.26 \mathrm{~b} \pm 0.005$ & $3.12 \mathrm{a} \pm 0.005$ & $3.52 \mathrm{ab} \pm 0.007$ \\
\hline F7 & $0.30 \mathrm{a} \pm 0.005$ & $1.14 \mathrm{c} \pm 0.002$ & $2.97 \mathrm{bc} \pm 0.005$ & $3.37 \mathrm{~b} \pm 0.021$ \\
\hline F8 & $0.27 \mathrm{~cd} \pm 0.003$ & $1.41 \mathrm{a} \pm 0.005$ & $3.19 \mathrm{a} \pm 0.015$ & $3.68 \mathrm{a} \pm 0.010$ \\
\hline
\end{tabular}

Note: Numbers represent mean values of three independent replicates \pm SD. In the same data column, values with similar letters represent non-significant differences, values with different letters represent differences in significance $(P \leq 0.05)$.

F4 $\left(1.28 \mathrm{~m}^{2} / \mathrm{m}^{2}\right)$ and the lowest was found in F1 $\left(1.08 \mathrm{~m}^{2} / \mathrm{m}^{2}\right)$. LAI values increased more significantly at the beginning of harvesting. At this stage, the maximum LAI was observed in F8 at $3.19\left(\mathrm{~m}^{2} / \mathrm{m}^{2}\right)$, followed by F3 $\left(3.17 \mathrm{~m}^{2} / \mathrm{m}^{2}\right)$ and the minimum was obtained in F1 $\left(2.87 \mathrm{~m}^{2} / \mathrm{m}^{2}\right)$. After the harvesting, the highest LAI value was recorded at $3.71\left(\mathrm{~m}^{2} / \mathrm{m}^{2}\right)$ in F5, followed by F8 $\left(3.68 \mathrm{~m}^{2} / \mathrm{m}^{2}\right)$. These results were in agreement with those of Hossain et al. (2017) on tomato LAI [22].

Experimental results show that in treatments with the application of micronutrient fertilizer such as F3, F5, F8, LAI values were recorded higher than in other treatments although the lowest value was always found in the control. It proves that the application of isolated $\mathrm{GA}_{3}$, micronutrient fertilizer, $\mathrm{Ca}\left(\mathrm{NO}_{3}\right)_{2}$ foliar fertilizer or their mixture can all increase the LAI value. Therefore, it can be stated that $\mathrm{GA}_{3}$, micronutrient fertilizer and $\mathrm{Ca}\left(\mathrm{NO}_{3}\right)_{2}$ foliar fertilizer all have effects on the yield of tomato.

Yield components and yield. Yield and yield components are important criteria to assess the effects of elements on the plant [24]. The studied results were shown in Table 5.

Table 5

Yield and yield components of tomato

\begin{tabular}{|c|c|c|c|c|}
\hline Formula & $\begin{array}{c}\text { Number of fruits } \\
\text { per plant }\end{array}$ & $\begin{array}{c}\text { Average fruit } \\
\text { weight }(g)\end{array}$ & $\begin{array}{c}\text { Actual yield } \\
\text { per plant }(\mathrm{kg})\end{array}$ & $\begin{array}{c}\text { Conversion yield } \\
\text { (tons }^{-1} \text { ) }\end{array}$ \\
\hline F1 & $25.54 \mathrm{c} \pm 0.029$ & $82.19 \mathrm{~d} \pm 0.674$ & $2.10 \mathrm{~d} \pm 0.008$ & $39.90 \mathrm{~d} \pm 0.034$ \\
\hline F2 & $27.55 \mathrm{~b} \pm 0.045$ & $86.94 \mathrm{~b} \pm 0.405$ & $2.40 \mathrm{~b} \pm 0.019$ & $45.60 \mathrm{~b} \pm 0.056$ \\
\hline F3 & $26.49 \mathrm{bc} \pm 0.107$ & $85.58 \mathrm{c} \pm 0.268$ & $2.27 \mathrm{c} \pm 0.006$ & $43.13 \mathrm{c} \pm 0.102$ \\
\hline F4 & $27.12 \mathrm{~b} \pm 0.097$ & $85.42 \mathrm{c} \pm 0.357$ & $2.32 \mathrm{c} \pm 0.014$ & $44.08 \mathrm{c} \pm 0.149$ \\
\hline F5 & $28.15 \mathrm{~b} \pm 0.242$ & $87.08 \mathrm{~b} \pm 0.095$ & $2.45 \mathrm{~b} \pm 0.054$ & $46.55 \mathrm{~b} \pm 0.036$ \\
\hline F6 & $27.93 \mathrm{~b} \pm 0.015$ & $89.32 \mathrm{a} \pm 0.175$ & $2.49 \mathrm{~b} \pm 0.009$ & $47.31 \mathrm{~b} \pm 0.083$ \\
\hline F7 & $27.86 \mathrm{~b} \pm 0.026$ & $86.64 \mathrm{~b} \pm 0.286$ & $2.41 \mathrm{~b} \pm 0.026$ & $45.79 \mathrm{~b} \pm 0.018$ \\
\hline F8 & $29.52 \mathrm{a} \pm 0.058$ & $90.36 \mathrm{a} \pm 0.078$ & $2.67 \mathrm{a} \pm 0.032$ & $50.73 \mathrm{a} \pm 0.065$ \\
\hline
\end{tabular}

Note: Numbers represent mean values of three independent replicates \pm SD. In the same data column, values with similar letters represent non-significant differences, values with different letters represent differences in significance $(P \leq 0.05)$. 
It can be easily seen that different formulas resulted in radical differences in the number of fruits per plant (Table 5). F8 produced the highest values of the number of fruits per plant at 29.52 fruits, followed by F5 with 28.15, F6 with 27.93 and F7 with 27.86. The lowest numbers were obtained in F1 at 25.54 fruits and F3 at 26.49 fruits. It can be pointed out that the combination of micronutrient fertilizer and $\mathrm{Ca}\left(\mathrm{NO}_{3}\right)_{2}$ foliar fertilizer and $\mathrm{GA}_{3}$ increased the number of fruits per plant. Additionally, applying $\mathrm{GA}_{3}$ and $\mathrm{Ca}\left(\mathrm{NO}_{3}\right)_{2}$ foliar fertilizer or $\mathrm{GA}_{3}$ and micronutrient fertilizer also increased fruit set percentage when compared to the control. Despite isolated application, $\mathrm{GA}_{3}, \mathrm{Ca}\left(\mathrm{NO}_{3}\right)_{2}$ foliar fertilizer and micronutrient fertilizer still contributed to an improvement in the number of fruits per plant, the efficiency was not as good as the ones in the formulas of their mixture.

The average fruit weight was also various from different formulas (Table 5). The same trend was observed in this criterion when F8 had the highest average fruit weight at $90.36 \mathrm{~g}$, followed by F6 at $89.32 \mathrm{~g}$ and F5 at $87.08 \mathrm{~g}$. F1 produced the lowest figure at $82.19 \mathrm{~g}$, followed by F4 at $85.42 \mathrm{~g}$. These ranges were statistically significant. So, it can be concluded that mixing micronutrient fertilizer and $\mathrm{Ca}\left(\mathrm{NO}_{3}\right)_{2}$ foliar fertilizer and $\mathrm{GA}_{3}$ in F8, F6 and F5 led to an increase in fruit weight. Meanwhile, applying $\mathrm{Ca}\left(\mathrm{NO}_{3}\right)_{2}$ foliar fertilizer and micronutrient fertilizer or supplementing fertilizers separately showed a slight improvement in fruit weight which was lower than combination formulas.

The actual yield per plant and conversion yield show a close relationship among the average fruit weight and the number of fruits per plant with obtained individual yield (Table 5). F8 resulted in the highest yield at $2.67 \mathrm{~kg}$, which was equivalent to 50.73 tons ha ${ }^{-1}$. In the following places were F6, F5 and F7 at $2.49 \mathrm{~kg}$ (equivalent to 47.31 tons $\mathrm{ha}^{-1}$ ), $2.45 \mathrm{~kg}$ (equivalent to 46.55 tons ha- ${ }^{-1}$ ) and $2.41 \mathrm{~kg}$ (equivalent to 45.79 tons $\mathrm{ha}^{-1}$ ) respectively. The lowest ones were observed in F1 (the control) at $2.10 \mathrm{~kg}$ which was equivalent to 39.90 tons ha ${ }^{-1}$, followed by F3 and F4. All the formulas produced a higher yield than the control and the differences were statistically significant. This means $\mathrm{GA}_{3}, \mathrm{Ca}\left(\mathrm{NO}_{3}\right)_{2}$ foliar fertilizer and micronutrient fertilizer increased the yield of tomato when cultivated in the condition of the experiment and when being combined, they provided better effects.

Correlation between some growth indicators and yield of tomato. Growth indicators are correlated with crop yield; therefore, correlation graphs (Fig. 1) were used to evaluate which indicators more closely correlated with the yield. It should be noted that during the growth process, the flowering stage is the essential one contributing to crop yields [19]. Consequently, we use correlation graphs at the beginning of the flowering stage to demonstrate this correlation.

It can be seen that among analyzed indicators (Fig. 1), the number of fruits per plant showed the strongest correlation with yield $(r=0.99)$, followed by average fruit weight per plant $(r=0.97)$. Obviously, these two indicators had direct effects on the yield of tomato. The number of flowers per plant also had fairly close correlation with yield $(r=$ $=0.88)$ while leaf area index and plant height had significant influence on the yield $(r=0.83$ and $\mathrm{r}=0.82$ respectively). 

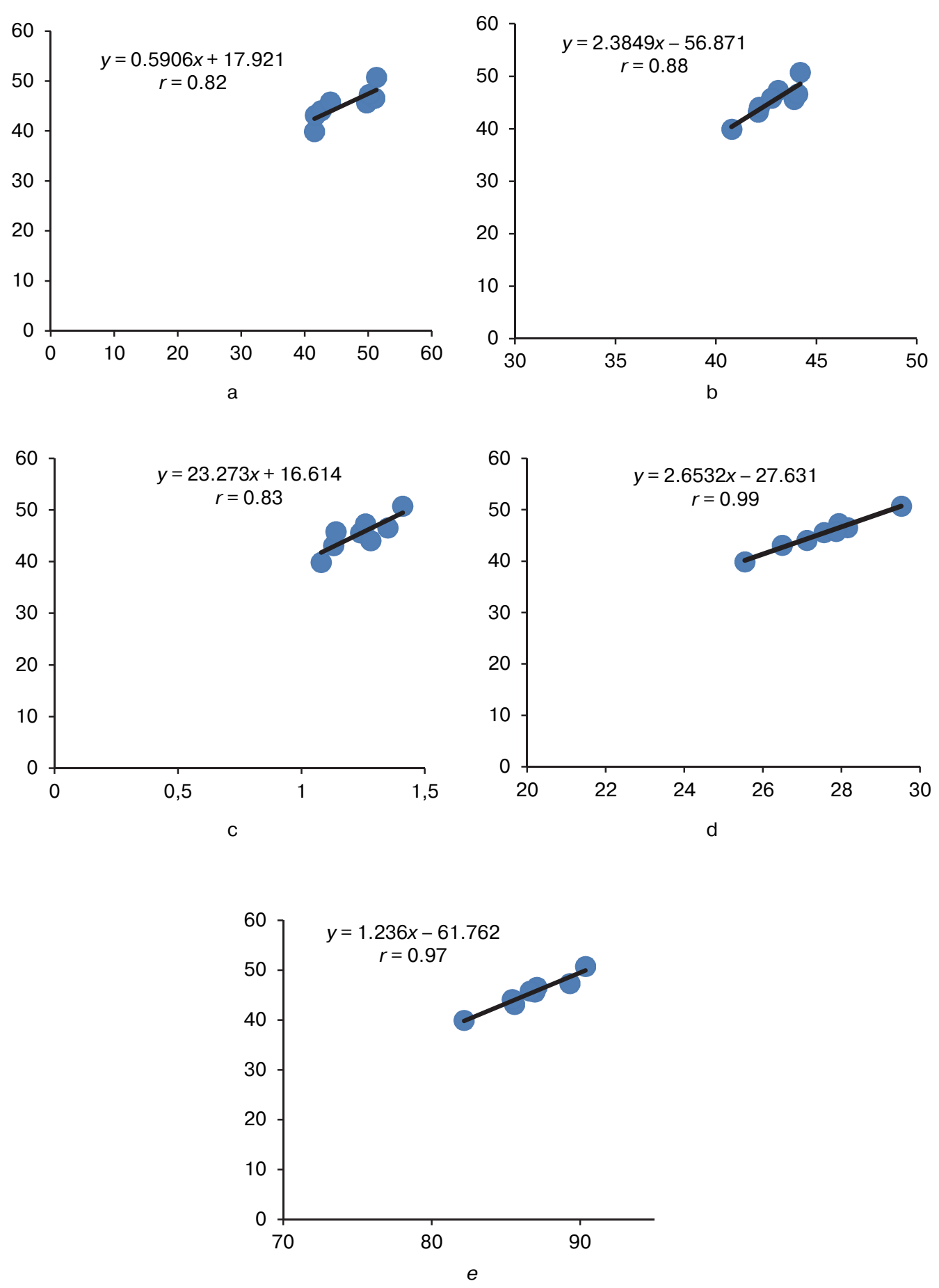

Fig. 1. Correlation between some growth indicators and yield of tomato:

$a$ - between plant height and yield; $b$ - between number of flowers per plant and yield; $c-$ between LAl and yield; $d$ - between number of fruits per plant and yield; $\mathrm{e}-$ between average fruit weight and yield 


\section{Conclusions}

Having been supplemented with $\mathrm{GA}_{3}$, micronutrient fertilizer and $\mathrm{Ca}\left(\mathrm{NO}_{3}\right)_{2}$ foliar fertilizer, tomato (Solanum lycopersicum L.) cultivated in net houses grew faster and better when compared to the control. The results were from some indicators such as plant height, leaf area index, number of flowers per plant, effective flower rate, number of fruits per plant, average fruit weight and actual yield. The formula in which mixed $\mathrm{GA}_{3}$, micronutrient fertilizer and $\mathrm{Ca}\left(\mathrm{NO}_{3}\right)_{2}$ foliar fertilizer produced the highest yield at 50.73 tons $\mathrm{ha}^{-1}$, followed by the one in which mixed $\mathrm{GA}_{3}$ and $\mathrm{Ca}\left(\mathrm{NO}_{3}\right)_{2}$ foliar fertilizer at 47.31 tons $\mathrm{ha}^{-1}$. The formula of $\mathrm{GA}_{3}$ and micronutrient fertilizer was in the third place with 46.55 tons $\mathrm{ha}^{-1}$ while the fourth-place belonged to the formula of $\mathrm{Ca}\left(\mathrm{NO}_{3}\right)_{2}$ foliar fertilizer and micronutrient fertilizer with 45.79 tons $\mathrm{ha}^{-1}$. Other formulas which supplemented separately $\mathrm{GA}_{3}$, micronutrient fertilizer and $\mathrm{Ca}\left(\mathrm{NO}_{3}\right)_{2}$ foliar fertilizer also produced yield higher than the control (yield of the control was 39.9 tons ha $\mathrm{h}^{-1}$ ); however, the figure was not as high as the mixed formulas.

\section{References}

1. Costa JM, Heuvelink E. The global tomato industry. In: Heuvelink E. (ed.) Tomatoes. Boston, USA: CABI; 2018; p. 1—26. doi: 10.1079/9781780641935.0000

2. Beecher GR. Nutrient content of tomatoes and tomato products. Proceedings of the Society for Experimental Biology and Medicine. 1998; 218(2):98—100. doi: 10.3181/00379727-21844282a.

3. Fattore M, Montesano D, Pagano E, Teta R, Borrelli F, Mangoni A, Seccia S, Albrizio S. Carotenoid and flavonoid profile and antioxidant activity in "Pomodorino Vesuviano" tomatoes. Journal of Food Composition and Analysis. 2016; 53:61 - 68. doi: 10.1016/j.jfca.2016.08.008

4. Trong LV, Tuong LQ, Thinh BB, Khoi NT, Trong VT. Physiological and biochemical changes in tomato fruit (Solanum lycopersicum L.) during growth and ripening cultivated in Vietnam. Bioscience Research. 2019; 16(2):1736-1744.

5. Martí R, Roselló S, Cebolla-Cornejo J. Tomato as a source of carotenoids and polyphenols targeted to cancer prevention. Cancers. 2016; 8(6):58. doi: 10.3390/cancers8060058

6. Xu X, Li J, Wang X, Wang S, Meng S, Zhu Y, Liang Z, Zheng X, Xie L. Tomato consumption and prostate cancer risk: a systematic review and meta-analysis. Scientific reports. 2016; 6:37091. doi: 10.1038/srep37091

7. Cheng HM, Koutsidis G, Lodge JK, Ashor A, Siervo M, Lara J. Tomato and lycopene supplementation and cardiovascular risk factors: A systematic review and meta-analysis. Atherosclerosis. 2017; 257:100 - 108. doi: 10.1016/j.atherosclerosis.2017.01.009

8. Paroussi G, Voyiatzis DG, Paroussis E, Drogoudi PD. Growth, flowering and yield responses to $\mathrm{GA}_{3}$ of strawberry grown under different environmental conditions. Scientia Horticulturae. 2002; 96(1-4):103-113. doi: 10.1016/S0304-4238(02)00058-4

9. Ronen E. Micro-elements in agriculture. Practical Hydroponics and Greenhouses. 2016; (164):35- 44 .

10. Korkmaz N, Askin MA, Ercisli S, Okatan V. Foliar application of calcium nitrate, boric acid and gibberellic acid affects yield and quality of pomegranate (Punica granatum L.). Acta Scientiarum Polonorum-Hortorum Cultus. 2016; 15(3): 105-112. 
11. Gale HF, Hansen J, Jewison M. China's growing demand for agricultural imports. USDA-ERS Economic Information Bulletin. 2015; (136).

12. Parry MAJ, Flexas J, Medrano H. Prospects for crop production under drought: research priorities and future directions. Annals of Applied Biology. 2005; 147(3):211-226. doi: 10.1111/j.1744-7348.2005.00032.x

13. Zeidan MS, Mohamed MF, Hamouda HA. Effect of foliar fertilization of Fe, Mn and Zn on wheat yield and quality in low sandy soils fertility. World Journal of Agricultural Sciences. 2010; 6(6): 696-699.

14. Tiwari DK, Pandey P, Giri SP, Dwivedi JL. Effect of GA3 and other plant growth regulators on hybrid rice seed production. Asian journal of plant sciences. 2011; 10(2):133-139. doi: 10.3923/ajps.2011.133.139

15. Anjum A, Raj N, Nazeer A, Khan SH. Genetic variability and selection parameters for yield and quality attributes in tomato. Indian Journal of Horticulture. 2009; 66(1):73-78.

16. Wang Y, Zhao J, Lu W, Deng D. Gibberellin in plant height control: old player, new story. Plant cell reports. 2017; 36(3):391-398. doi: 10.1007/s00299-017-2104-5

17. Narimani H, Rahimi MM, Ahmadikhah A, Vaezi B. Study on the effects of foliar spray of micronutrient on yield and yield components of durum wheat. Archives of Applied Science Research. 2010; 2(6):168-176.

18. Aksic MF, Rakonjac V, Nikolic D, Zec G. Reproductive biology traits affecting productivity of sour cherry. Pesquisa Agropecuária Brasileira. 2013; 48(1):33-41. doi: 10.1590/S0100204X2013000100005

19. Alburquerque N, Burgos L, Egea J. Influence of flower bud density, flower bud drop and fruit set on apricot productivity. Scientia Horticulturae. 2004; 102(4):397-406. doi: 10.1016/j.scienta.2004.05.003

20. Nammidevi M, Shalini B, Bhongle SA, Khiratkar SD. Effect of bio-inoculants with graded doses of NPK on flowering, yield attributes and economics of annual chrysanthemum. Journal of Soils and Crops. 2008; 18(1):217-220.

21. Singh AK, Beer K, Pal AK. Effect of vermicompost and bio-fertilizers on strawberry growth, flowering and yield. Annals of Plant and Soil Research. 2015; 17(2):196-99.

22. Hossain SAAM, Lixue W, Taotao C, Zhenhua L. Leaf area index assessment for tomato and cucumber growing period under different water treatments. Plant, Soil and Environment. 2017; 63(10):461-467. doi: 10.17221/568/2017-PSE

23. Heuvelink E, Bakker MJ, Elings A, Kaarsemaker RC, Marcelis LFM. Effect of leaf area on tomato yield. In International Conference on Sustainable Greenhouse Systems-Greensys2004. 2004; 691:43-50. doi: 10.17660/ActaHortic.2005.691.2

24. Hannan MM, Biswas MK, Ahmed MB, Hossain M, Islam R. Combining ability analysis of yield and yield components in tomato (Lycopersicum esculentum Mill.). Turkish Journal of Botany. 2007; 31(6):559-563.

\footnotetext{
About authors:

Le Van Trong - Doctor of Sciences in Biology, Faculty of Natural Sciences, Hong Duc University; 565, Quang Trung st., Dong Ve Ward, Thanh Hoa city, Vietnam; e-mail: bbt.9895@gmail.com

Bui Bao Thinh - School of Natural Sciences, Far Eastern Federal University; 8 st. Sukhanova, Vladivostok, Russian Federation; e-mail: buibaothinh9595@gmail.com
} 


\title{
Влияние гибберелловой кислоты, микроудобрения и внекорневого удобрения - нитрата кальция на рост и урожайность томатов Solanum Iycopersicum L. , выращиваемых во Вьетнаме
}

\author{
В.Ч. Ле ${ }^{1}$, Б.Т. Буй ${ }^{2 *}$ \\ ${ }^{1}$ Университет Хонгдык, Тханьхоа, Вьетнам \\ ${ }^{2}$ Дальневосточный федеральный университет, \\ Владивосток, Российская Федерация \\ *bbt.9895@gmail.com
}

\begin{abstract}
Аннотация. Приведены экспериментальные результаты, оценивающие влияние гибберелловой кислоты $\mathrm{GA}_{3}$, микроудобрения и внекорневого удобрения - нитрата кальция $\mathrm{Ca}\left(\mathrm{NO}_{3}\right)_{2}$ на рост и урожайность томатов сорта NHP11, выращенных в закрытом грунте. Исследования проводились в провинции Тханьхоа, Вьетнам. Эксперимент, включающий 8 вариантов, был составлен в рандомизированном полном блочном дизайне с тремя повторностями. При обработке с применением $\mathrm{GA}_{3}$, микроудобрения и внекорневого удобрения $\mathrm{Ca}\left(\mathrm{NO}_{3}\right)_{2}$ наблюдали более высокие показатели роста и развития растений (высота растения, индекс листовой поверхности, количество цветков на растение, эффективная норма цветения, количество плодов на растение, средняя масса плодов на растение) по сравнению с контрольным вариантом. Показатели урожайности томата отличались по вариантам эксперимента. Наивысшая урожайность 50,73 т/га была обнаружена в варианте F8 при применении комбинация $\mathrm{GA}_{3}$, микроудобрения и внекорневого удобрения $\mathrm{Ca}\left(\mathrm{NO}_{3}\right)_{2}$, в $\mathrm{F} 6$ с использованием $\mathrm{GA}_{3}$ и внекорневого удобрения $\mathrm{Ca}\left(\mathrm{NO}_{3}\right)_{2}$ урожайность составила $47,31 \mathrm{t} /$ га, в $\mathrm{F} 5$ с использованием $\mathrm{GA}_{3}$ и микроудобрения - 46,55 т/га, в F7 с использованием внекорневого удобрения $\mathrm{Ca}\left(\mathrm{NO}_{3}\right)_{2}$ и микроудобрения - 45,79 т/га. Урожайность томатов в вариантах F2, F3, F4 при обработке с использованием $\mathrm{GA}_{3}$, микроудобрения и внекорневого удобрения $\mathrm{Ca}\left(\mathrm{NO}_{3}\right)_{2}$ в отдельности была соответственно выше, чем в контроле $(39,90$ т/га), но ниже, чем в комбинированных вариантах. Полученные результаты показывают, что комбинация $\mathrm{GA}_{3}$, микроудобрения и внекорневого удобрения $\mathrm{Ca}\left(\mathrm{NO}_{3}\right)_{2}$ может способствовать росту и урожайности томатов.
\end{abstract}

Ключевые слова: томат, Solanum lycopersicum, гибберриловая кислота, $\mathrm{GA}_{3}$, микроудобрения, внекорневая подкормка, удобрение, нитрат кальция, $\mathrm{Ca}\left(\mathrm{NO}_{3}\right)_{2}$, рост, урожайность

\section{Благодарности:}

Авторы признательны Университету Хонгдык (Hong Duc University, Vietnam) за поддержку данного исследования.

\section{Вклад авторов:}

Ле В.Ч.: разработка дизайна исследования, получение данных для анализа, анализ полученных данных, написание первоначального текста рукописи; Буй Б.Т.: разработка дизайна исследования, получение данных для анализа, анализ полученных данных, написание и редактирование рукописи.

\section{Конфликт интересов:}

Авторы заявляют об отсутствии конфликта интересов. 


\section{История статьи:}

Поступила в редакцию: 18 августа 2019 г. Принята к публикации: 11 октября 2019 г.

\section{Для цитирования:}

Le V.T., Bui B.T. Effects of Gibberellic acid, micronutrient fertilizer and Calcium nitrate foliar fertilizer on growth and yield of tomato Solanum lycopersicum L. cultivated in Vietnam // Вестник Российского университета дружбы народов. Серия: Агрономия и животноводство. 2019. Т. 14. № 4. C. 306 -318. doi: 10.22363/2312-797X-2019-14-4-306-318

\section{Об авторах:}

Ле Ван Чонг - доктор биологических наук, факультет естественных наук, Университет Хонгдык; 40130, Вьетнам, г. Тханьхоа, Уорд Донг Вэ, ул. Куанг Чунг, 565; e-mail: bbt.9895@gmail.com

Буй Бао Тхинь - Школа естественных наук, Дальневосточный федеральный университет; Российская Федерация, 690920, г. Владивосток, ул. Суханова, д. 8; e-mail: buibaothinh9595@gmail.com 